Journal of Economics and Behavioral Studies

Vol. 4, No. 1, pp. 66-71, Jan 2012 (ISSN: 2220-6140)

\title{
The Impact of Marketing Mix and Market Orientation on Export Performance
}

\author{
${ }^{*}$ Muhammad Usman, Irfan Ullah, Muhammad Bilal Kayani, Faisal Haroon, Muhammad Aslam Khan \\ Iqra University Islamabad, Pakistan \\ *usman_sher77@yahoo.com
}

\begin{abstract}
The study focuses on the marketing mix and market orientation on export performance due to the significance of foreign businesses. Theory posits that marketing mix and market orientation have a positive impact on export performance. Although the paper is conceptual base and the model proposed is required to check their reliability that firm with size, information system, and commitment with availability of market mix and market orientation formally. However, with the modification of technology enhances the export performance in a better way. The authors concluded that the practical implementation of export's marketing strategies identically facilitated the companies for future success.
\end{abstract}

Keywords: Firm's commitment, export-marketing strategy, marketing mix, market orientation

\section{Introduction}

Now a days exporting is considered as the one of the key access approach in the foreign markets and usually this field has created more interest for both organization and scholars. Besides the significance of export, the management indeed promotes the improvement or modification of the corporation to enhance functions in the export markets. Behaviors of the management about the export, Aaby \& Slater's (1989) and Zou \& Stan's (1998) have decided to provide a major function to export commitment. While determining the levels of firm's export commitment, state governments creates suitable types of support such as learning approaches are launched that are focusing on the generations of revenues that built worldwide trade fairs and more attractiveness to the significance of export (Singer and Czinkota 1994). Kotler (2003) and Webster (1992) have discussed that Marketing Mix is a basic theory which is based on optimization to produce recommendations through what ways to obtain a best possible mixture of the 4 Ps (Product, Price, Place and Promotion) as controllable parameters that influence the buying behaviors of consumers and to make better decisions regarding the commodities.

Different firms from different countries who have large domestic markets show a very little attention to the needs of their international markets (Calantone et al. 2004). Sorenson and Wiechmann (1975) discussed that if multinational companies (MNCs) want to compete their competitors successfully, then they have to standardize their decision "process" of marketing by creating an identified system for their annual marketing planning. Foreign markets enforce the other exporting firms to identify the idiosyncrasies to follow few adaptations to marketing-mix strategies to maintain the uniqueness from all markets more intimately and reduce psychological distance of foreign consumers as well. The consequences of market orientation on the outcome of firm are influenced by the controlled distance as well as complication of the market orientation performance association; also, the contradictory consequences were obtained in research (Kirca et. al 2005). Narver and Slater (1990) recommended that organization's management needed to become market oriented and maintained it was linked with permanent creation of greater value and long term profit.

\section{Literature Review}

The firms who have a little contribution in exports partially face problems to obtain right valuable export information sources (Armario et. al 2008). Francis and Collins-Dodd (2000) argue about the firm size that built the quantity of financial, human, and organizational capital and their prominent persuasion to the export orientation. Organizations that had businesses in the foreign markets are becoming more experienced also their awareness, familiarity and recognition with export markets will be increased. In the success and failure 
of the firm, information plays a critical role. Marketing department generated all the required customer information alone, it is probable that it is generated by service personnel when they conduct survey on clients. Such type of information performs an instrumental use to solve a particular problem by directly using the information, also it can be used to increase managerial knowledge that helps them ultimately to made better decision making in future (Diamantopoulos and Souchon, 1999).

According to Kacker (1975) top management philosophies key function is export commitment, also the goals of an organization are the responsibility of particular management to be committed more to export to become more beneficial. Become argued that resource availability is associated with commitment. Researches have shown that without export commitment, a company can not increase its performance (Beamish et al. 1993). In the history, export commitment is considered or possibility aspect that it had an affirmative affects at international marketing strategy, which is in the appearance of outcome shows performance. The responsibility of the exporters is to create strategies directing the possible ways that how to implement suitable Strategies by applying proper mechanism to accomplish their organizational objectives. Donthu and Kim (1993) have defined that export commitment like the management of firm's enthusiasm is to assign adequate decision-making, financial, and human assets to exporting activities.

Kotler (1971) has discussed that it is specifically be understood to kept in mind that the Marketing Mix is a normative study, the founders of that techniques are frustrating in order to resolve the dilemma that how to extend a most favorable Marketing Mix containing product, place, price and promotion proofs. It is necessary for a firm to have appropriate knowledge regarding the foreign markets, they were more easily to made decisions about the adaptations of 4Ps (Products, Prices, Place and Promotions) comparative to the existing firms with the need of such knowledge to built their decisions on the center of sensitivity (Cadogan and Diamantopoulos 1995). Export's marketing strategy would be observe inside the organization as multiple decision which includes strategic orientation with its preferred scale of homogeny of the strategic mix resources such as the guideline for the distribution of assets between marketing mix variables, advertising, promotion, personal selling etc. In addition, its preferred scale of standardization of the strategies is established to achieve the organizational export performance (Shoham 1996 \& Szymanski et. al 1993). Needs, wants and desires of each state firm enable the management to have knowledge and perform the activities in proactive way (Racela et. al 2007). Significant resource investments must be considered necessary for a company to perform export better in the way of market-oriented.

Tariffs and tacit complicity between the present companies with emerging markets might discourage competition, with the development of country's markets have created complicated consumers whose expectations are high quality due to competitive markets (Porter 1990). Miscellaneous results were founded while studying on the association among variation of standardization and company's performance (Calantone et al. 2004). Unless the markets have not been properly defined that is why strategies implementation problems arises which causes the lack of difference in performance (Samiee and Roth 1992). The business strategy is restrained by the association between market orientation and its performance (Matsuno and Mentzer, 2000). Competitive strategies of export companies are designed under the way of resource and potential exploitation that were maintained by the companies to compete their target customers and helpful in achievement of desired goals (Cavusgil and Zou, 1994). The dominant goal of exporting firms is to operational survival by increasing their growth and securing their assets regarding to other similar firms. A firm potential to achieve and maintain export performances is intimately associated with the efficiency and effectiveness of implementation to a deliberate export marketing strategy (Sousa et. al, 2008).

Market orientation is defined as activities including the creation of market intelligence that is applicable with the exporting firms operations, distribution of an effective knowledge to make suitable assessment along with responses of export consumers helpful to design and implement strategies, factors like export competitors can influence the firm performance with its capability to offer greater importance to export customers. Export management operates funds and abilities in progressive strategic manner in order to accomplish competitive dominance in the form of efficient export performance in foreign markets (Morgan et. al., 2004). A foreign business operator's beneficial significance was providing to its consumers and price arrangement in creating the worth constrains its performance. 


\section{Hypothesis}

$\mathrm{H}_{0}$ : Marketing Mix has a significance effect on export performance.

$\mathrm{H}_{1}$ : Firm size, information System and commitment through marketing Mix increase the export performances.

$\mathrm{H}_{2}$ : Marketing Orientation has positive impact on the export performance.

Figure 1: Conceptual Model

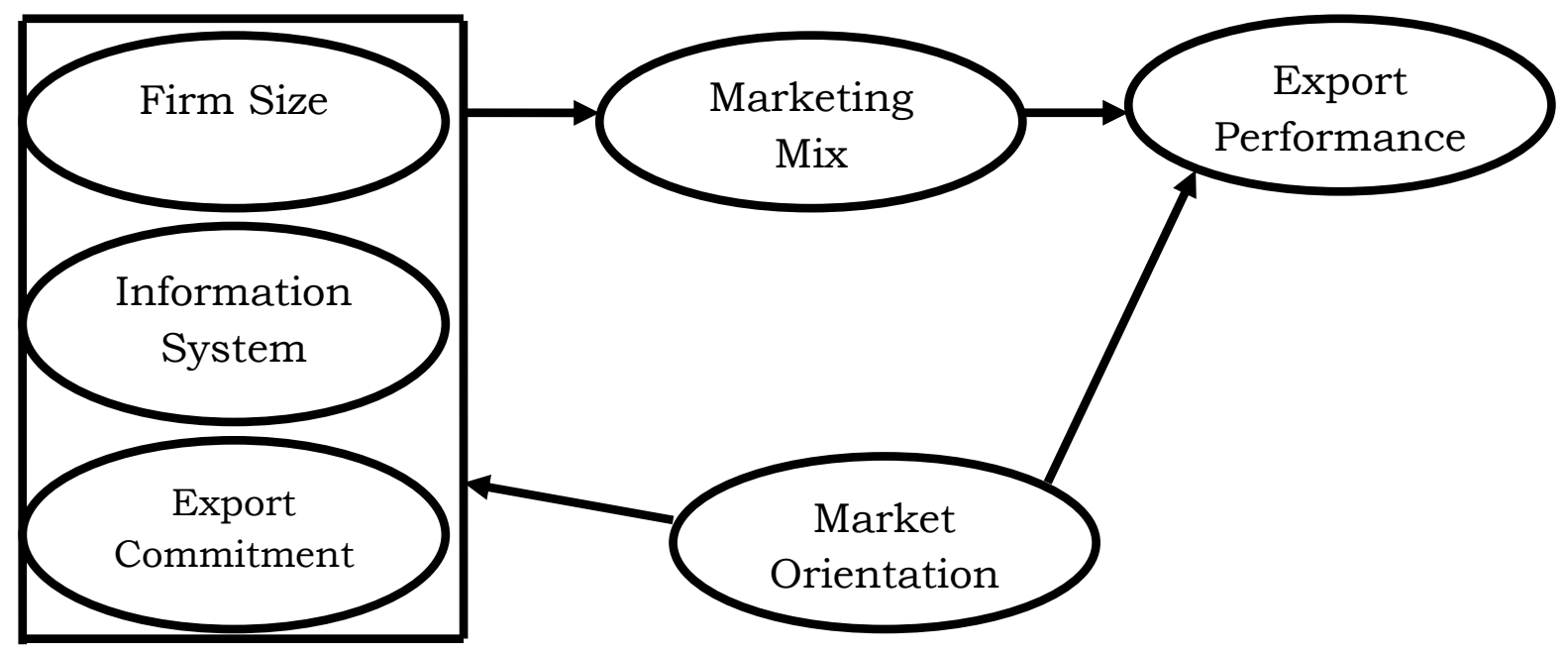

\section{Discussion}

Exporting concept is very vast due to its significance because companies are directed towards foreign businesses for the sake of their existences in world of competitiveness. The purpose of the study is to determine the factors that are increasing the worth of export because exporting is a key bone in the success or failure of any country's organization. The Firms that have little contribution to export face problems to earn better profits to compete their rivals. In the foreign country where the firm operates its business and they suffer from the huge losses is due to the reason that they are unfamiliar with their cultures. The customer's wants are varying with the passage of time and this can be considering by almost preference by the exporting firms to enhance well-being operation in the international exports. The size of the firm toward achieving the required targets matters the most as size of the firm is small they can more easily and more accurately control the functions and operations to run healthy exports and if the size of firm is larger than their resources, capitals and skill then they foster disease from a low outcome. With passage of time, the companies get more experience and are more familiar with foreign nation's values, norms, culture etc with the modification of practices to better satisfy their consumers.

The information system of the firm plays a sensitive role as the generation of personal information about the changing world and their focus on their clients enables them to make good decisions, select the best possible alternative that are helpful in the satisfaction of the customer and effective implementation of strategies can increase the volume of export sales. The complete evaluations of their clients help them to improve the level of products and services they offering. The commitment of the firm shows that how much they are severe with their exports resulted in the better performance. The most important factor is market orientation a business approach through which hidden or expressed needs and wants of consumer are identified while they are using it or want to acquire it. Before launching, any export business markets are identified and have a complete assessment of customer needs and wants, what products or services they are using and how their required wants are fulfilled by providing new products or services. Then the controllable factor which has a positive significance on the export performance is the Marketing Mix i.e. product, price, place and promotion which is also known as 4Ps. Significant research has focused on importance of marketing mix and market orientation that enabling the firm to the generation of profit. 
Our study has focused on the relationship of marketing mix and market orientation and their strong impact on the export performance. The world is full of competitiveness and in this competition; a need of benchmark is required to successful in the field of business. As the size of firm, its information and technology systems, commitment are those factors that encourage the firm to compete their competitors as the resources of the firm are according to new technology. The needs and wants of customer are varying so the organizations particularly have a complete focus on the market orientation to satisfy their customers to achieve their goals. Development of infrastructure can be kept in mind for continuous maintenance of the existing resources. Price of the product is affordable by the audience and they accept it when they are buying something in the markets, the placement, and the creation of awareness of these product and services matter the most to increase foreign export. International marketing strategies are held properly in order to operate functions and gain the desired outcomes. The firms needed to have a well focused on the market orientation and the cultural influences on the continuous change of customer needs and wants; also considering their demographical preferences as age, gender, occupation, education, religion etc through which their needs and wants are assessed more accurately, then well developed and organized system is launched to maintain and advance changes are occurring to compete the competitor's mind. As discussed earlier about the significance of export; companies are creating an advance informative and technological \& developmental system that enables the effective strategies to implement to satisfying the end consumers.

The outcomes are very clear that a firm wants to compete in the field of export than it must be market oriented with fully utilization of resources. It is assumed from the study that the resources include size; information and commitment have a positive influence on export performance through the consideration of marketing mix; also the marketing orientation have positive relation on the export performance. However, these few resources are considered in the study through marketing mix, which shows a positive result that helps to perform better operations in the establishment of foreign export. The study also shows that a firm who wants to gain competitive edge in exporting they must have better resources and their effective implementation through marketing mix and marketing orientation increase their export performance. With the significance of resources as the firm required to make a competitive edge in the field of export the results are in the favor of the firm. It is recommended from the study that export performance will therefore be increased by modifying current system and with effective utilization of resources.

Practical Implications: As a whole, the significance of this research is considered reliable in the midst of the expected conjecture. The model proposed here is found vigorous for the better assessment of the required factors. Concerning on the export performance, the factors like size, information system and commitment contributes in the improvement of product and services and their effect delivery to the end consumers. For instance, the marketing mix and market orientation have significance to influence the international customers. Export companies must identify their consumer's needs and wants and will have a complete focus on them and utilization of their resources to best by the achievement of desired goals. The authors are argued about the high lightening of changing phenomena that was occurring in aggressive competition of export. Now companies are well aware of their end consumers and they are managing the consequences that are fostering in the ways of success.

\section{Conclusion and Recommendations}

The results are very clear from theory as the conceptual model proposed here is not practically tested by means of surveys, questionnaire, etc but we have found a significant relationship among the independent factors and the dependent factors. The hypothesis $\mathrm{H}_{0}$ that we have proposed in our study as Marketing Mix has a significance effect on export performance; authors have found a positive result from the study. The hypothesis $\mathrm{H}_{1}$ as firm size, information System and commitment through marketing Mix increase the export performances, the results are different because if the organization focuses on these factors with more persistence the results are in their favor but if they are ignoring one of these factors, they will face different outcomes. The hypothesis $\mathrm{H}_{2}$ : Marketing Orientation has positive impact on the export performance, the authors also found a positive result that the market orientation consideration will definitely increase the export performance. With the significance of all these factors' effect on the export performance the authors recommended that due to the change of global system of export must be according to the requirements that 
enabling the firm to facilitate their resources with better implementation of export strategies they earn high profits to survive and success for the future.

Limitations and Direction for Future Research: The study is suffered from several limitations. First limitation is that the conceptual model proposed in this paper is not formally tested i.e. by mean of questionnaire, surveys, interviews etc to check them practically in the eyes of customer or audience. Second limitation is that we only focused on few variables that are essentially dependent on the export performance like firm size, information system and export commitment that enables the firm to promote their export performance. Future research should be constructed on many other dependent factors. Third limitation is that our proposed study is focusing on a single country organization, future research should be constructed to consider others country's organization. Fourth limitation involves a deep study of the dependent variables with marketing mix and market orientation is required that influence their audience to increase the profitability of the export. Finally, a complete view of the organizational strategies and external factors are required to be focusing in the future research.

\section{References}

Aaby, N. E. \& Stanley, F. S. (1989). Management Influences on Export Performance: A Review of the Empirical Literature 1978-1988. International Marketing Review, 6(4), 7-26.

Armario, J. M., David, M. R. \& Armario, M. E. (2008). Market Orientation and Internationalization in Small and Medium-Sized Enterprises. Journal of Small Business Management, 46(4), 485-511.

Beamish, P. W., Ron, C. \& Kerry, M. (1993). The Performance Characteristics of Canadian versus U.K. Exporters in Small and Medium Sized Firms. Management International Review, 33(2), 121-137.

Cadogan, J. W. \& Diamantopoulos, A. (1995). Narver and Slater, Kohli and Jaworski and the Market Orientation Construct: Integration and Internationalization. Journal of Strategic Marketing, 3(1), 4170.

Calantone, R. J., Tamer, C. S., Jeffrey, B. S. \& Shin, G. C. (2004). Internationalization and the Dynamics of Product Adaptation-An Empirical Investigation. Journal of Product Innovation Management, 21(3), 185-198.

Diamantopoulos, A. \& Souchon, A. L. (1999). Measure Export Information Use: Scale Development and Validation. Journal of Business Research, 46(1), 1-14.

Donthu, N. \& Kim, S. H. (1993). Implications of Firm Controllable Factors on Export Growth. Journal of Global Marketing, 7(1), 47-63.

Francis, J. \& Collen, C. D. (2000). The Impact of Firms' Export Orientation on the Export Performance of HighTech Small and Medium-Sized Enterprises. Journal of International Marketing, 8(3), 84-103.

Kacker, M. P. (1975). Export Oriented Product Adaptation: Its Patterns and Problems. Management International Review, 15(6), 61-70.

Kotler, P. (1971). Marketing Decision Making: A Model Building Approach, New York: Holt, Rinehart and Winston.

Kotler, P. (2003). Marketing Management, 11* Edition, Prentice Hall International Editions

Kirca, A. H., Satish, J. \& William, O. B. (2005). Market Orientation: A Meta-Analytic Review and Assessment of Its Antecedents and Impact on Performance. Journal of Marketing, 69, 24-41.

Matsuno, K. \& Mentzer, J. T. (2000). The Effects of Strategy Type on the Market Orientation-Performance Relationship. Journal of Marketing, 64(4), 1-16.

Morgan, N. A., Anna, K. \& Katsikeas, S. C. (2004). Antecedents of Export Venture Performance: A Theoretical Model and Empirical Assessment. Journal of Marketing, 68 (January), 90-108.

Narver, J. \& Slater, S. F. (1990). The Effect of Market Orientation on Business Profitability. Journal of Marketing, 54(4), 20-35.

Porter, M. E. (1990). Competitive Advantage of Nations, New York: Free Press.

Racela, O. C., Chawit, C. \& Amonrat, T. (2007). Market Orientation, International Business Relationships and Perceived Export Performance. International Marketing Review, 24(2), 144-63.

Samiee, S. \& Roth, K. (1992). The Influence of Global Marketing Standardization on Performance. Journal of Marketing, 56(1), 1-17. 
Singer, T. O. \& Michael, R. C. (1994). Factors Associated with Effective Use of Export Assistance. Journal of International Marketing, 2(1), 53-71.

Shoham, A. (1996). Marketing-Mix Standardization: Determinants of Export Performance. Journal of Global Marketing, 10(2), 53-73.

Sousa, C., Francisco, M. P., Martínez-López, J. \& Filipe, C. (2008). The Determinants of Export Performance: A Review of the Research in the Literature between 1998 and 2005. International Journal of Management Reviews, 10(4), 343-74.

Sorenson, R. Z. \& Wiechmann, U. E. (1975). How Multinationals View Marketing Standardization. Harvard Business Review, 53 (May-June), 38-54, 166-167.

Szymanski, D. M., Sundar, G. B. \& Varadarajan, P. R. (1993). Standardization versus Adaptation of International Marketing Strategy: An Empirical Investigation. Journal of Marketing, 57, 1-17.

Webster, F. E. (1992). The changing role of marketing in the corporation. Journal of Marketing, 56(4), 1-17.

Zou, S. \& Simona, S. (1998). The Determinants of Export Performance: A Review of the Empirical Literature between 1987 and 1997. International Marketing Review, 15(5), 333-56. 